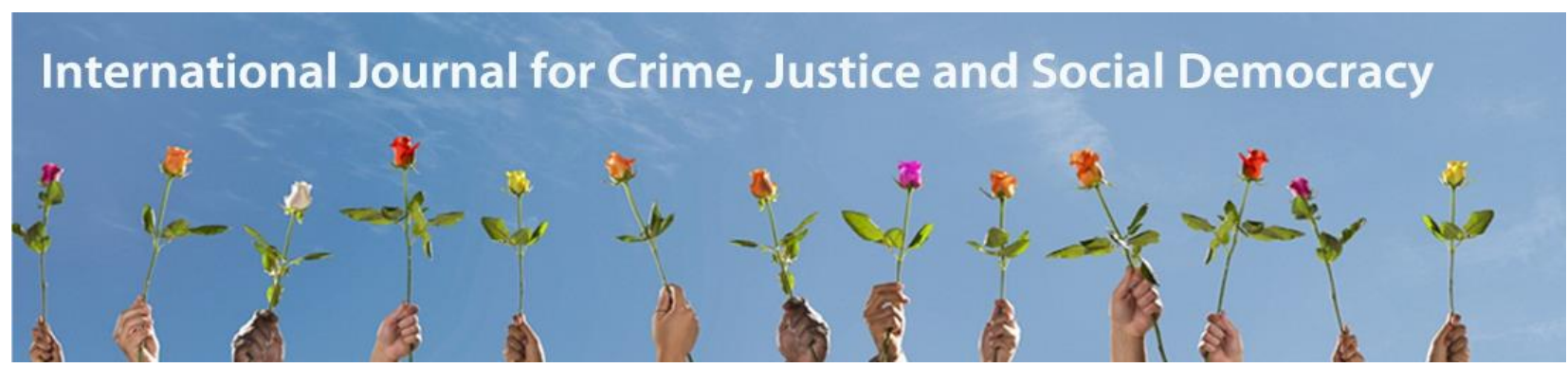

\title{
Gender, Vulnerability and Everyday Resistance in Immigration Detention: Women's Experiences of Confinement in a Portuguese Detention Facility
}

\section{Francesca Esposito}

University of Oxford, United Kingdom; APPsyCI - Applied Psychology Research Center Capabilities \& Inclusion, ISPA-IU, Portugal

\section{Raquel Matos}

Universidade Católica Portuguesa, Research Centre for Human Development, Portugal

\section{Mary Bosworth}

University of Oxford, United Kingdom; Monash University, Australia

\begin{abstract}
This paper examines immigration detention by looking at women's experiences of confinement in a Portuguese detention facility. The empirical data-comprising participant observations, informal conversations and interviews with detained women-are read through an intersectional lens. This approach illuminates constructions of gender and sexuality in their mutual and contextualised articulation with other power relations (e.g., processes of racialisation and ethnicisation stemming from colonial histories), as well as the reconfiguration of these constructions by women themselves. Doing so also focuses on the intertwinement between power and resistance in daily life in detention. The women we met did not passively accept their situation, but rather struggled to make sense of, navigate and challenge the detention system. To this effect, they deployed multiple forms of agency, which also passed through the rejection, acceptance and reappropriation of hegemonic gendered constructions and their use in strategic ways to negotiate their positions vis-a-vis the system.
\end{abstract}

\section{Keywords}

Gender; vulnerability; resistance; immigration detention; Portugal; colonialism.

Please cite this article as:

Esposito F, Matos R and Bosworth M (2020) Gender, vulnerability and everyday resistance in immigration detention: Women's experiences of confinement in a Portuguese detention facility. International Journal for Crime, Justice and Social Democracy 9(3): 5-20. https://doi.org/10.5204/ijcjsd.v9i3.1588 


\section{Introduction}

There is growing public and scholarly debate around the implementation of detention and deportation policies and their effect (e.g., Bosworth 2016; von Werthern et al. 2018). Despite large levels of interest, however, little academic research has been conducted into the embodied realities of people in these sites of confinement, as these highly politicised and contested institutions remain difficult places for researchers to access (Bosworth 2014; Kirmayer, Rousseau and Crépeau 2004; Robjant, Hassan and Katona 2009; Steel and Silove 2004). In this context, the experiences of women have been particularly overlooked (although, see Bosworth, Fili and Pickering 2016; Bosworth and Kellezi 2014; Canning 2017).

Existing work on women's experiences of immigration detention in the context of European border control is mostly based on studies carried out in the United Kingdom (UK) (Bosworth 2014; Bosworth and Kellezi 2014; Canning 2017; De Angelis 20201), Greece (Bosworth, Fili and Pickering 2016, 2018) and Italy (Esposito, Ornelas, Scirocchi et al. 2019). This body of work sheds light on the gendered aspects of the lives of women labelled as 'unauthorised non-citizens' before, during and after their confinement. These studies also reveal racialised logic of citizenship and nationality on which detention relies and how it is imbued with ideas about gender and sexuality.

Most women whose stories are recounted in these contributions report experiences of gender violence in their countries of origin and in transit. Their experiences range from restrictions on their liberty and selfdetermination related to gendered norms and prescriptions, to forced marriages, domestic violence, and rape (Bosworth, Fili and Pickering 2018; Bosworth and Kellezi 2014; Esposito, Ornelas, Scirocchi et al. 2019). To escape these situations and change their lives for the better, women often embarked on difficult journeys to European destinations, during which they were exposed to multiple forms of abuse. Many report extensive experiences of sexual violence, especially those travelling to Italy or Greece.

Problems do not always end upon arrival. Rather, interlocking relations of power including gender, racialisation, class and sexuality also affected women's lives in their countries of destination. In some cases, moving to a new country exacerbated their gendered vulnerabilities and powerlessness, as the threat of being apprehended by State authorities and of being deported often prevented women from accessing social and healthcare services. Indeed, and despite the violence they endured, most women were not entitled to any form of legalisation and protection, as they fell outside the narrow categories recognised by the State (e.g., the category of refugee or trafficking victim) (Esposito, Ornelas, Scirocchi et al. 2019). The illegalisation they suffered also enhanced their risk of entering abusive and exploitative relations, both intimately and at work.

Firsthand accounts reveal that gender also matters in detention, where it shapes the perceptions and expectations of detainees and staff alike (Bosworth 2014; Bosworth and Slade 2014; Esposito, Ornelas, Scirocchi et al. 2020). Both groups draw on gendered and sexualised (as well as racialised) identities, stereotypes and norms to make sense of their own and others' experience, to interact with each other, and to cope with and navigate detention's uncertain and volatile environments. Overall, this body of scholarship unveils the gendered nature of the immigration detention regime (Alberti 2010), while problematising the complex relationship between oppressive forces and women's capacity to resist them. In doing so, these contributions ultimately challenge the dominant understanding of detention centres as 'symbolic zones of exclusion, peopled with "non citizens"' (Bosworth and Kellezi 2014: 92), presenting them instead as contested sites of struggle.

As far as Portugal is concerned, information about immigration detention is particularly scant. Not only has very little research been produced on migrant detention (for exceptions see Sacramento and Ribeiro 2011; Santos et al. 2018), but also public debate on this topic is almost non-existent (for exceptions see Gorjão Henriques 2018a, 2018b, 2019). ${ }^{2}$ Unsurprisingly, nobody has (yet) explicitly addressed gender issues. Instead, we must turn to work by Matos (2016), which has shown how categories such as gender, nationality and 'race/ethnicity' play a fundamental role in the paths of foreign national women in the Portuguese prison system. 
Based on evidence provided by this study, Matos and Esposito (2019) started to analyse the trajectories of women confined in Portugal for migration-related reasons. This preliminary work-which focused on women's pathways to illegalisation and detention, as well as on their expectations for the future-found that gender plays a crucial role in their experiences of mobility and crossing borders. The women in this study recounted a variety of reasons for their migration. Many wished to escape abusive relationships and gendered forms of control. They, and others, also hoped for better working conditions and the ability to live out their lives as they pleased, on their own terms. However, and as their accounts revealed, the 'precarious life' (Butler 2004) women sought to escape through migration persisted in Portugal. Sexism, violence and exploitation, although materialised in different forms and through other means, continued to affect them. In intersection with other social markers-such as nationality, race, and class-gender exacerbated the vulnerability of these women as produced by their unsecure immigration status, while also amplifying their powerlessness in interpersonal domains. Notwithstanding this evidence, women's stories also revealed instances of agency, protagonism, and resistance.

In this paper we expand on our initial findings by focusing on women's lived experiences of detention. In particular, drawing on field notes and interviews carried out in Portugal's detention centre (currently named Centro de Instalação Temporária-CIT), we examine women's experiences and understandings of detention within a framework that aims to capture constructions of gender and sexuality at the intersection with other systems of oppression (on the notion of intersectionality see, for instance, Collins 2000; Crenshaw, 1991). Adopting such an approach entailed for us the setting of two related goals. First, we aim to contribute to the feminist body of scholarship about immigration detention regimes and women's experiences of confinement in the context of European border control. Particularly, we aim to provide insight on the gendered and sexualised aspects that permeate the lives of a group of women we know little about, within a largely under-researched Southern European setting (i.e., Portugal). In line with other feminist scholars working on migration-related issues (e.g., Giuliani 2018; Padilla, Gomes and Fernandes 2010), we argue that these aspects intersect with colonial histories and processes of racialisation/ethnicisation ${ }^{3}$ operating at both local and transnational levels.

Second, this work examines the complex relation between power and everyday resistance in these contemporary sites of confinement. As others have found elsewhere (e.g., De Angelis 2020), the women we met did not passively accept the repression and control exerted on them but rather struggled to make sense of, and further navigate and challenge, the detention system. Within the limited opportunity structures and everyday spaces available to them, they made claims, actively negotiated and (re)defined their subject positions, and created new psychosocial praxis (Lykes 2013).4 This psychosocial praxis also included the reappropriation of hegemonic gendered (and racialised) constructions and norms, and their use in strategic - or even counter-hegemonic - ways, to oppose the violence and dehumanisation of the detention system. By adopting this standpoint, and in line with other scholars (Hughes 2016; on the prison system see Bosworth 1999), we acknowledge the dynamic, complex and contested nature of life in detention, as well as the multifaceted and intrinsically entangled relationships between power and resistance in these sites.

\section{Overview of the Portuguese Context of Immigration Detention}

In recent years, the Portuguese Immigration and Borders Service (SEF) have carried out an increased number of border checks in line with a global scenario of progressive securitisation of transborder migration (Huysmans 2000). As a result, more people have been identified without permission to enter or stay in the country and many of them have been deported ${ }^{5}$ (Serviço de Estrangeiros e Fronteiras 2020). The last available figures on immigration detention indicate that 2,444 people were placed in detention facilities in 2016, compared to 2,071 in 2015 (Provedor de Justiça 2017). Although no data are available about these last years, it is reasonable to argue that the detention population has significantly increased as many of those who are affected by border control operations are also subject to detention.

The history of detention in Portugal dates back to 1994, when Act 34/94 of 14 September created detention facilities for people failing to comply with immigration or residency rules. This law listed three 
reasons as possible grounds for detention-(a) humanitarian reasons, (b) security reasons and (c) as a consequence of attempting to enter irregularly in the country. As a result, in 2000, five short-term holding facilities were created in the main Portuguese airports: Lisbon, Porto, Faro, Funchal and Ponta Delgada. These were complemented by a Centro de Instalação Temporária-CIT that opened in 2006. To date, this centre is the sole detention facility in the Portuguese territory and has the official mission to hold 'in dignified and human conditions' (Decree-Law 44/2006) up to 30 people (men, women, and eventually their children) subject to a 'removal order'. As observed in other countries, such as Belgium (Crosby 2016) or Italy (Campesi 2015; Esposito, Ornelas, Scirocchi et al. 2020), these sites, and the migration management regime more generally, rely on a close articulation between humanitarian and security rationalities. Among other things, this articulation, and particularly what has been defined as a humanitarian government of migration (Agier 2011; Fassin 2012), plays a crucial role in legitimising detention in the eyes of the public.

In 2007, the Act 23/2007 of 4 July (Aliens Act ${ }^{6}$ ) regulated the entry, stay and exit of foreign-national citizens into and out of the Portuguese territory, as well as their 'removal'. According to this Act:

The foreign citizen who illegally enters or stays in national territory shall be detained by a police authority and, when possible, handed over to SEF with the respective police report. The citizen shall be presented within forty eight-hours at the most to the judge of the lower criminal court [juízo de pequena instância criminal] under his/her jurisdiction or to the district court in other areas of the country, in order to validate and possibly enforce coercive measures. (Article 146 (1), Act 23/2007)

The same article of the Act states also that no 'coercive removal procedure' shall be organised against foreign nationals who, having entered the national territory irregularly, submit an application for asylum to any police authority within 48 hours of their entry, and that, in this case, the applicants waits at liberty for the decision on their asylum claim. However, subsequent Acts 27/2008 and 26/2014, which revised the national asylum regulation and aligned it with the European directives, have amended this last point, defining procedures for detaining asylum seekers in specific circumstances. ${ }^{7}$ It is finally worth noting that Act 23/2007 (Aliens Act) foresees an 'accessory penalty of expulsion' when foreign nationals who are not residing in the country are sentenced to more than six months of imprisonment or given a fine, or when foreign nationals residing in the country are condemned for an intentional crime punished with more than one-year sentence. In the case of foreign nationals who are permanent residents, instead, the accessory expulsion penalty can only be applied when 'their conduct constitutes a sufficiently serious threat to public order or national security' (Article 151 (1) (2) (3)). As a result of these provisions, after serving a prison sentence some people end up being confined in immigration detention centres. In all these cases (i.e., illegalised migrants, asylum seekers and former prisoners), detention cannot exceed 60 days, or 90 days in special circumstances and following a judicial order (Article 160).

In the detention facility where we conducted our fieldwork, in 2019144 people were held, 129 of whom were adults (92 men and 37 women, age range: 18-69 years) and 15 were children (age range: 6 months7 years). Ten were asylum seekers. The average detention duration was 31 days (minimum time: 1 day; maximum time: 89 days), and detainees were mainly from Brazil (20), Iran (14) and Cape Verde (10). Among the 37 women detained, the majority were from Brazil (10). Finally, according to data provided by the Jesuit Refugee Service-JRS Portugal (2020), only 38 detainees were effectively deported, while in 41 cases they were released, after they reached the maximum term for detention. ${ }^{8}$ Many of those released continue to be undocumented and, although they live in the community, they are prevented from accessing basic rights available to other citizens (e.g. healthcare, welfare programmes, employment) (JRS Portugal 2018). Furthermore, they are likely to end up being detained again, thus remaining stuck in a vicious cycle with no way out (on the sociopolitical processes of 'illegalisation' and 'detainability' see De Genova 2002, 2016). 


\section{A Note on Methodology}

This paper relies on field notes as well as informal conversations and interviews carried out inside the CIT. ${ }^{9}$ In addition to observing the regime of daily life in detention and the interactions between different actors (i.e., staff, volunteers, immigration officers and migrants detained), we conducted interviews with 10 women, ${ }^{10}$ whose ages ranged from 18 to 49 , to better understand their experiences and perspectives. The interviews took the form of life stories and focused on the women's lives before Portugal, including their migration motivations and trajectories. We also covered their life after arrival, their experiences of immigration control and detention and, finally, their views about the future.

Before starting the interview, we informed participants about the nature and aims of the study, as well as the procedures for guaranteeing anonymity and confidentiality. Women were also asked to sign a consent form in their native language or, when this was not possible, in a language they understood. ${ }^{11}$ The interviews were digitally recorded and transcribed verbatim, except in the case of one participant who did not agree to audio record and so her interview was handwritten. All transcripts were subsequently analysed through a thematic narrative analysis (Lykes and Hershberg 2015; Riessman 2008), whose results are reported here and in a previous article about migration pathways, life in Portugal and expectations for the future (Matos and Esposito 2019).

Consistent with our critical feminist research engagement, it is important to acknowledge the privileged position from which we produce our work and from which we wrote this paper. We are white, have academic affiliations and, above all, are citizens of countries of the Global North (a privilege which allows us a high freedom of movement). Solidarity to us means using our research to witness and support the struggles of the women we meet in our research work. So, we strive not to impose on them our academic agendas and views, but rather seek to be faithful to their accounts and perspectives, in the context of a broader commitment towards constructing knowledge from the base of their experiences. Yet, even if we problematise the circuits of power within which we are implicated, we are aware that the knowledge built through processes in which privileged intermediaries like us accompany people who struggle against extreme conditions of injustice and oppression is always hybridised, and transitional (Lykes 2013). Indeed, some community psychologists define this as a 'third voice' (Lykes 2013; Lykes, Blanche and Hamber 2003).

\section{Migration-related Detention and the Legacies of Colonialism}

Despite the great heterogeneity of nationalities and trajectories, the people we met inside the detention facility were largely people of colour, and many of them came from a background of poverty. As in other detention contexts (e.g., Bosworth 2017; Bosworth and Kellezi 2014), including the national prison system (Matos 2016), the detention population also reflected the country's colonial history. Thus, a considerable proportion of the people confined came from former parts of the Portuguese overseas empire, such as Brazil or Cape Verde. In particular, reflecting broader historical and contemporary migration trends in Portugal,12 the majority of the women we interviewed (i.e., seven out of 10) were Brazilians. Most of them-and of our participants more generally—had experiences in the sex industry.

As feminist scholars have pointed out, a persistent imaginary that associates Brazilian women with a hypersexualised and an available body marks the everyday life of these women in Portugal (Gomes 2013, 2018; Padilla 2008; Piscitelli 2008a). This imaginary, which harks back to Portuguese colonial history and the related ideology of lusotropicalism, ${ }^{13}$ is upheld and reinforced through media accounts, institutional discourses and mundane social interactions (de Reno Machado 2009; Gomes 2018). The core thesis of lusotropicalism, 'the Portuguese way of being in the world', refers, according to Castelo (1998), to the idea of a Portuguese 'self' characterised by positive attributes such as tolerance, fraternity, vocation for interracial coexistence, and the ecumenical ideal of Christianity. Evidence of this Portuguese ability to 'unite with the tropics' (and create a so-called 'racial democracy') was, above all, the openness of Portuguese colonisers towards miscegenation, defined by Freyre as the Portuguese's 'special aptitude for 
having sexual intercourses with women of "different colours"' (Castelo 1998: 111, translation by the authors).

The centrality of miscegenation in Portuguese colonial ideology, especially from the mid-1950s, illuminates the close relationship between colonial and masculine sexual dominations (de Reno Machado 2009), or, in other terms, between racism and heteropatriarchy in the construction of the Portuguese imagined community (on this point see also Giuliani 2018; Stolke 2006). Therefore, it is within the context of this relationship, and of the ways colonial hierarchies were (re)elaborated through the gendered opposition of civilisation/savagery, that the sexualised and sensual image of a mix-raced Brazil, as well as the role of Brazilian women who migrate to Portugal today (especially those working in the sex industry), are structurally located. Indeed, as Padilla, Gomes and Fernandes (2010:118) argue:

all Brazilian women, married or single, more or less young, because they are Brazilian, they are seen as potential prostitutes, as easy women or [as those] who came to Portugal interestedly to marry a Portuguese [man]. (translated by the authors)

The story of Franciele (also called Fran), ${ }^{14}$ a 49 -year-old Brazilian woman, who had been detained for 20 days at the time of our fieldwork, illuminates these issues well. In Brazil, Fran used to work in construction and agriculture, where she was exposed to harsh labour conditions and low salaries. Having emigrated to Portugal in 2011 to improve her life, Fran fell in love with a Portuguese man but, unable to legalise her situation, received an expulsion order (notificação para abandono voluntário) and had to go back to Brazil. In 2014, she managed to return to Europe-first to France, where her Portuguese boyfriend was working, and then again to Portugal, where she continued to live as an undocumented migrant and occasionally worked in the sex industry. It was during her nightwork that Fran was apprehended by the police and detained. Recalling this episode, she described an excess of authority and the feeling of being treated like a 'criminal'.

In detention, Fran told us, the quality of life was not so bad: by making an effort to comply with the rules and act like a 'good detainee' she was able to avoid trouble and serve her time quietly. The real problem, in her view, laid in the practice of administrative detention itself and the depersonalisation of the system. She also complained that the 'Portuguese don't like us (Brazilians) a lot'15. Some security guards, she believed, enjoyed seeing her suffer. Fran associated her experiences in the CIT with the broader discrimination suffered by Brazilian people in Portugal, which included the gendered stereotype of Brazilian women seducing Portuguese men to take advantage of their financial resources. By contrast, Fran described relationships among the detainees as positive and an important source of support.

Fran was not the only woman who had been arrested during sex work nor to allege mistreatment by police or other institutional authorities. Emilia, a 47-year-old Brazilian woman who arrived in Portugal nine years earlier after facing economic difficulties and ending her marriage, also told us that the police caught her while she was working in a night bar. Like Fran, Emilia complained about the way police officers and the judge who validated her detention order expressed their sexist attitudes:

There was the prosecutor next to the judge, and I was in the front, [with] my lawyer, do you know what the judge said? 'My wretched (desgraçada) wife is in the bed, hungry, and I want to hurry this up.' And in a hurry to leave, calling his wife a wretch (desgraçada)?!

During all the years she lived in Portugal, Emilia, like the majority of the other women we met, struggled to legalise her situation but without any success ('the chances were very small'). Unable to achieve a regular status, she continued to make her ends meet by working in the sex market. For Emilia, 'sex work was work' and, as such, was considered worthy of respect. In putting forward this claim, Emilia challenged the disparaging vision of Brazilian women, reasserting their dignity as 'women' and 'workers'. Yet, she did so by proposing, in opposition, a moralising view of women's sexual freedom: 
Brazilian women are prostitutes! Whores are those women who do [sex] for love, do [sex] for one man and then for another, go out with one man and then with another, kiss on the mouth, it's like this. They're whores, and the other ones [Brazilians] are prostitutes, they're there to earn their money, right!?

Unlike Fran, Emilia said the staff treated her well inside the detention centre and overall had a good quality of life. Yet, she was looking forward to returning to Brazil: 'I just want to arrive to my country ... and hug my family,' she asserted. Although anxious to get out of the centre, Emilia noted that the experience of confinement, even though it was hard, was filled with meaning. In particular, she had found that contact with other people with more difficult life trajectories taught her how to value her own life.

Not all the women interviewed displayed the same assertiveness and self-confidence as Emilia. For example, Carla (33 years old, who had been in detention for only two days when we met her) had a different attitude. She had endured poverty and domestic violence in Brazil, and had been living in Portugal for nearly five years. During this time, she had worked as a maid and occasionally supplemented her earnings with sex work. Carla was ashamed of this experience and said no-one in her family knew about it. During the interview, she also revealed that she had been in a romantic relationship with a married Portuguese man for the past three years. According to her, it was because of him that she had stopped working in the sex industry: Carla's hope was that he would have now divorced his wife and married her, to prevent her deportation. Indeed, detention was difficult. She had not been expecting to be confined and she felt isolated and suffocated inside the centre. Above all, she struggled to make sense of why her liberty had been taken away.

Despite their individual differences, the accounts of Fran, Emilia and Carla all point to the salience of the hypersexualisation imaginary concerning Brazilian women in Portugal. As Piscitelli (2008a, 2008b) notes, the sex and marriage markets (and their frequent overlapping) are the main industries in which the racialised notion of 'sensuality' associated with Brazilian femininity becomes embodied. For those we interviewed, such hypersexualisation was intertwined with a criminalising rhetoric about people on the move.

As in the last years transborder mobility has been increasingly securitised, the general imaginary of migrants as a threat to national security reinforces the specific imaginary of Brazilian women as equally threatening to the national moral order (Gomes, 2018). To understand this reality, the story of the 'Mothers of Braganza' (Maes de Bragança), is illustrative. In 2003, a group of women from Bragança, a town in Northern Portugal, accused the estimated 300 young Brazilian women who had moved there to engage in sex work as 'bewitching' their husbands. Through protests and petitions to drive them out of town, the 'mothers' called for a 'war on prostitution' (see Machado 2011). This campaign, which received vast national and international media coverage, ${ }^{16}$ represented Brazilian women as 'sinners' who sought to destroy marriages and families. By contrast, Portuguese women were depicted as exemplary mothers and brides who preserved the moral values of the nation (Gomes 2018; Padilla, Gomes and Fernandes 2010). Repressive police actions that followed saw the persecution of the Brazilian women, who were arrested due to their illegalised status, without acknowledging the violent and explorative conditions endured by many of them (for more details on the case see Cunha 2005; Pontes 2004).

This analysis, which emphasises how women are differently constructed (from men) as a threat to the 'white body of the nation' (Giuliani 2018), can be extended to all migrant women who end up in the sex labour market. Indeed, as Gomes (2018: 426) observes:

prostitution does not constitute a crime in Portugal, however, it is also not a regulated profession that can fulfil the requirements for a residence permit. Thus, immigrants who opt for prostitution cannot be legalised, but also cannot be criminalised for prostitution. In this way, they are criminalised as illegal immigrants or perceived as victims of trafficking. 
Indeed, even when women actually fall under this last 'category' (i.e., victims of trafficking), ${ }^{17}$ similar mechanisms of abjection and dispossession are deployed. State authorities often display a stereotyped vision of these women, trapped between a moralising and victimising view of their past and a pervasive control and disciplining of their present (Esposito, Murtaza, Peano et al. 2020; Peano 2012; Rigo 2019; Taliani 2012). To be entitled to protection, these women must demonstrate they are at risk of danger and persecution, while complying with a narrow understanding of what counts as a victim with a 'credible' story. They have also to prove that 'coercion' played a crucial role in their migration and further provide verifiable information relevant for criminal prosecution. As a result, many women are not able to get access to legal safeguards and become a target of state-sponsored violence, which includes their arrest, detention (often for extensive periods and in very harsh conditions) and, eventually, deportation (Esposito et al. 2016; Esposito, Ornelas, Scirocchi et al. 2019; Rigo 2019).

Julia's testimony encapsulates the difficulties women face. An 18-year-old Nigerian woman who had been detained for 17 days when we met her, Julia had arrived in Portugal less than one month before. In our interview she described a tortuous journey from Nigeria to Europe. Similar to the accounts of other women trafficked from Nigeria (Esposito et al. 2016; Esposito, Ornelas, Scirocchi et al. 2019; Taliani 2012), her story involved several stages, each one characterised by multiple obstacles and extreme violence. After all the difficulties she experienced, Julia was apprehended by the police in the city of Porto, where her exploiters had forced her into sex work. Although it was clear that she was a victim of trafficking and exploitation, Julia was detained without receiving adequate information from the police about her case and was also asked to sign papers, which she did not properly understand. Therefore, when we met her, Julia was very confused about what was going on with her life and about where she was. Speaking about her life in detention, she told us she was treated with respect by the centre staff. Nonetheless confinement was dehumanising: 'there is no life here,' she emphasised.

Such confusion and uncertainty about detention has been documented by others (e.g., see Bosworth 2014; Griffith 2013; Turnbull 2016) and was evident among a number of the women we interviewed. Like Julia, for instance, Iris, a 27-year-old Sri-Lankan woman, told us that no-one had provided her with adequate information on her situation. Her case was further complicated by the lack of Sri Lankan translators, and by the fact that all the conversations with police and SEF officers were conducted in English-a language she did not fully understand. Iris had been a member of the Tamil liberation movement and, along with her family, had actively participated in the Sri Lankan Civil War. Following the defeat of the Tamil Tigers, Iris had been imprisoned in a camp by the Sri Lankan military, where she had been forced into prostitution. Released in 2015 and still at risk, Iris decided to flee to Europe using a fake passport. She was stopped by the SEF at Porto's airport while she was trying to get to the UK, and was taken into detention (where, at the time of our encounter, Iris had spent eight days). As with the other women, Iris felt she was in prison. She complained about the lack of freedom, the strict regulation of everyday life and the lack of activities provided. Her confinement and the loneliness she felt as a result, were greatly affecting her wellbeing: 'I can't sleep well, I can't use the phone, anything ... and I can't use watch.' Although she had reported her traumatic story to the relevant authorities, immigration officers at the centre doubted her account, fearing she was telling a 'manufactured story of victimhood' to be released and obtain humanitarian protection (on similar evidence in the British context see Baillot, Cowan and Munro 2014; Canning 2017).

Overall, the tendency of authorities to doubt the genuineness of women's accounts-especially when presenting gaps in the details provided-emerged frequently in our fieldwork, coupled with the idea that women were involved in trafficking networks but did not want to share information about them. This was the case of several asylum-seeking women who arrived in Portugal from sub-Saharan Africa and were found pregnant: the risk of exploitation, not only of the women but also (and primarily) of their future babies, was the main argument used in this situation by State authorities to justify their detention (personal field notes, 5 December 2017). 


\section{Making Sense, Negotiating and Challenging the Gendered Regime of Detention}

Gendered norms and expectations affected women's everyday life in detention, including how they made sense of and dealt with their experiences of confinement. In particular, the women we met and spoke with often navigated the detention system by adhering and reproducing, but also reappropriating and performing, hegemonic constructions of femininity and vulnerability.

For example, Helena-a 21-year-old Brazilian woman who had been in detention for two weeks, and at the time of our encounter was four-months pregnant-complained about not receiving proper help for her pregnancy-related problems, such as morning sickness. She also criticised the fact that her 'vulnerability' (as a woman undergoing a risky pregnancy) was not acknowledged. Helena had left her family home in Brazil at the age of 16 due to conflict with her parents over their conservative views. Once she arrived in Portugal on a tourist visa, she began a relationship with a man much older than her, who became abusive. Confident that Helena could not leave because of her economic, social and legal vulnerabilities, this man was psychologically and physically violent to her and flirted with other women. One of these women subsequently denounced Helena to immigration authorities. Having failed to comply with the expulsion order she received, Helena was finally arrested during a police search in her partner's house (when he was being investigated for drug-related offences) and then detained. During her interview, Helena explained that inside the centre she felt sick, but that the staff did not believe her complaints and refused to take her to the hospital. Angry about this situation, Helena claimed that the body was hers and that she was the only one who knew what she was actually feeling: 'they [centre staff] don't know what am I going through. I know how it is, what I am going through.' In such claims, she used her identity as a pregnant woman to denounce the unfairness of the detention system and claim her rights, especially to health and care: 'I can't suffer like this, it is no good for me, this is no good for the baby, because I feel it and he feels it too.'

Overall, the medical certificate for a risky pregnancy was, according to Helena, the tool to oppose her deportation: she could not travel in such a vulnerable condition and, moreover, in Brazil could easily be affected by the Zika virus. Discussing her life in detention, Helena mentioned that she had fallen in love with Cape Verdean man who was also detained in the CIT (they actually met in there): she was happy about this relationship and dreamed about their future together once outside the centre. Above all, Helena emphasised how this relationship helped her, along with her faith, to cope with the detention experience, making it easier to bear (on the role of love in sites of confinement see also, Mehta 2014). The centre staff, however, did not share Helena's enthusiastic view. They regarded love between detainees as 'inappropriate' or even 'abnormal', especially since Helena was already pregnant by another man. Security staff strictly monitored the two lovers, and any type of physical contact between them was forbidden. Yet, Helena did not submissively accept such intrusive control in her intimate life:

They said that we can't have physical contact, but, um, I took the paper of the rules here and there isn't anything of that, because I know I can't sleep with him, because we have separate places and ... I know that, no, I know I can't, but having contact with him-physical-this is a normal thing. They're finding this abnormal because I'm pregnant; I said [to the staff], 'what's the problem, what is-'.

Another Nigerian woman, Anna, who was 22-years old and had been arrested at Lisbon's airport while travelling to Canada without regular documentation, was also pregnant when we met. Like Helena, Anna strategically used gendered constructions about women's pregnancy and its related vulnerability to challenge the harsh living conditions inside the centre and, overall, the unfairness of the detention system:

It's very difficult, very hard and I am pregnant ... It's very difficult, it hurts ... because of everything. The food is like shit! They are not feeding me, so I feel very tired. All I do is rest, sleep.

Having been detained for 35 days, Anna was particularly upset by the poor quality of the food provided, as well as the lack of activities and overall stimulation (see also Bosworth 2014; Esposito, Ornelas, Briozzo et 
al. 2019). Anna relied on religion to make sense of her confinement and cope with its uncertainty: 'Only God knows,' she claimed, speaking about her and her baby's future. ${ }^{18}$ Meanwhile, she firmly believed in her right to happiness 'in the present. Now.'

For those already with children, motherhood offered another basis on which to understand and oppose detention as well as to challenge the legitimacy of their deportation. Barbara's account, for instance, reveals how from a vulnerable position, this identity offered her a means to resist immigration control. Having arrived from Brazil when she was only 10, because her father was working in Portugal as an entrepreneur, Barbara fell into an abusive intimate relationship with a man, with whom she had a son. As an effect of this violence, Barbara was unable to look after her documents and ended up becoming 'irregular'. She explained, it was:

not that I had no motivation to take care of my papers, only that I had not ... I lived five years imprisoned. I didn't understand anything, I didn't know what to do.

Due to her overall lack of social and financial support, Barbara started working in a nightclub, but, like Carla, she was ashamed of this work and hid it from her family. She was in the nightclub when the police caught her.

Although Barbara said she received good treatment in the centre-where she had arrived two weeks before our interview-she described the experience of detention as 'horrible'. Having spent most of her life in Portugal and feeling more Portuguese than Brazilian, Barbara struggled to make sense of this form of administrative confinement, also complaining about the constant threats of deportation as 'a difficult psychological game'. In particular, her biggest fear was that she would separate from her three-year-old son. Accordingly, it was on her role as a 'mother' that Barbara ultimately relied to contest the legitimacy of the detention and deportation system:

My concern is with my son because he calls me, he cries, he says, 'Mum, where are you?' Right? I won't ... I won't send my son here to visit me, because for me this is a psychological torture for him too. I think that they [immigration authorities] should analyse more people's situation and not expose people like this ... They are aware that my life was in Portugal, my whole family is in Portugal.

Barbara also raised questions about the small number of women detained and the legitimacy of mixing women and men in the same institution. Some men, she said, particularly 'the Russians and the Ukrainians', were rude and intimated her. As a result, she ended up spending the majority of her time in her room, dwelling on her situation. Unlike some of the other participants we interviewed, Barbara described the security staff as sympathetic. In an unexpected echo of the colonial trope of the 'white men saving brown women from brown men' (Spivak 1988, p. 296), Barbara claimed that security guards acted as women's protectors, 'not letting the men [detainees] cross the line' with them.

Gendered norms and views were also evident in the case of Gloria, a 48-year-old Brazilian transgender woman who, at the time of her detention, was living with HIV and undergoing antiretroviral treatment. Abandoned by her father and mother, Gloria had grown up in rural Brazil with her grandmother and aunt. Since she was a child, Gloria was aware she was transgender, even if at that time she did not have the vocabulary for naming her experience. Finally, at the age of 17 , when her grandmother died, Gloria came out and started to work in the sex industry to pay for hormones and silicone. Believing that she could earn more money in Portugal and improve her life, Gloria decided to emigrate on a tourist visa and she lived in the north of Portugal for five years. There, she was caught in a bus by police and detained for five days before her interview with us. Although during her time in Portugal Gloria had been employed in 'regular' jobs, she was unable to legalise her situation. Speaking about the detention centre, Gloria emphasised the sense of oppression she felt, as well as her confusion about the type of site to which she had been taken: 'I came here, even though, in quotes, I feel totally in a jail, it's a reception facility [an immigration officer told her this], but we practically feel like we are imprisoned.' Like the other women Gloria opposed this 
criminalising effect of detention, claiming that, 'I'm leaving because I'm without documentation: I didn't kill and I didn't steal. I'm not a criminal.' In spite of her resistance to the system's dehumanisation, this experience was significantly affecting her wellbeing, to the extent that she reported not being able to sleep and to spend 'the whole night looking at, looking at, thinking a lot'.

Gloria's identity as a transgender woman challenged the cis-heteronormative, gender-binary view of centre staff and, overall, the everyday order of life in detention. Despite allowing her to sleep in the women's wing (where she was the only person detained at the time of our interview), the staff used to address Gloria by her official male name (i.e., the one reported on her passport) with which she no longer identified. In contrast, the other detainees did not contest Gloria's gender self-identification and called her by the name she chose for herself, thereby fully acknowledging her as a woman. It was their support, in addition to that shown by her friends outside, and above all her religious faith that helped Gloria to navigate through this difficult time of her life.

\section{Concluding Remarks: Insights on the Coloniality of Gender and Everyday Micro-politics of Resistance in Detention}

The limited empirical scholarship on immigration detention, understood through the experience of those confined, has largely overlooked the gender-specific perspectives of women. However, as Alberti (2010: 145) remarked, the 'systems of selection and "detention management" ' are gendered and, as such, they 'work to reproduce women's vulnerability'. At the same time, they also undermine women's agency and silence the political dimension of their embodied experiences. In turn, these systems ultimately uphold hegemonic gender norms and perpetuate heteropatriarchal interests. Our findings provide further support to Alberti's argument and, by contributing to the scarce literature in this field, highlight the gendered organisation of life in detention, and the gendered (and racialised) pains of this form of confinement.

Relying on women's own accounts of their experiences in detention helps to illustrate how the immigration system maintains a racialised and gendered social order in Western societies. It also highlights the centrality of the figure of the migrant prostitute/victim of trafficking in this process (Gomes 2018; Peano 2012). The criminalisation of transborder migration, through a progressive securitisation of borders, and the failure of Portuguese law (similarly to other EU countries) to recognise sex labour with the status of work, ultimately foster a racialised and gendered underclass. Moreover, as Taliani (2012: 599) observes, 'prostitution in the time of migration feeds a sexual economy inside a repressive system'. Therefore, she continues, these women, whose sexual performances are 'clandestine but at the same time easily accessible' (600), receive very low remunerations, being exposed to a condition of precarisation and exploitation, even when they work for themselves.

Our protagonists' accounts confirm this evidence, highlighting the particular value of migrant women's bodies in the Portuguese sex and marriage markets (Piscitelli 2008a, 2008b). As well, they highlight the effect of their criminalisation (as undocumented migrants) in making them productive as vulnerable gendered and racialised subjects (Peano 2012). This vulnerability, structurally imposed and differently distributed across lines of nationality, class and sexuality (among others), obfuscates women's agency, while increasing their exposure to arbitrary and state-sponsored (i.e., arrests, detentions and deportations) violence.

Moreover, the findings reveal the significance and pervasiveness (both in terms of mindset and structure) of colonial imaginaries and heteropatriarchal power relations in the everyday experiences of women in detention, especially but not exclusively Brazilian ones. This is what some scholars have defined as the 'coloniality of gender' (Lugones 2007, 2010; see also Gomes 2018). Overall, and despite their different nationalities, social classes and backgrounds, the women we met were affected by hegemonic images of femininity, which ultimately reinstate the age-old distinction between white women and women of colour - the first represented as Madonnas/mothers/brides and the latter as Evas/sinners/prostitutes (Gomes 2018; Stolke 2006). Not only did these racialised, gendered tropes serve to uphold the system and 
legitimate its existence, they also helped institutional actors, and at times women themselves, to make sense of their experiences (Bosworth 2014, 2017).

Yet, the relation of these women with the intersecting forms of power that influenced their lives inside (as well as outside) detention was not smooth, but rather marked by shades of opposition. Using the limited means and resources available to them, our participants pursued ways to make sense of and cope with their confinement and its related pains, as well as to negotiate power relations within the centre walls. In doing so, they relied on overt contestation but also on (apparent) compliance at various times, rejecting but also using hegemonic gendered images as part of their arsenal to negotiate their positions vis-a-vis the system and challenge the injustices endured (Piscitelli 2008a, 2008b). Finding romantic love (as in the case of Helena) or (re)appropriating hegemonic notions of femininity (like Fran, Carla and Emilia), including pregnancy (as Helena and Anna) and/or motherhood (as Barbara), and performing them, allowed them to restate their sense of self and battle against their expulsion and the stripping of their humanity brought by detention. Through these strategic performances, these women sought to survive confinement and challenge the restrictions placed upon them. They also challenged their criminalisation. In their stories, we catch a glimpse of ways women navigate a regime that denies their past, dictates their present and colonises their future (Bosworth 2014).

We conclude by arguing, in line with other scholars (e.g., Bosworth 1999; De Angelis 2020; Hughes 2016), that gender and sexualised norms and ideals-assumed, negotiated and reconfigured by women-play a crucial, albeit paradoxical, role in the complex nature of life in detention. As such, they became a constituent part of the plurality of expressions of women's resistance in these sites-sites where the power of the State is ultimately confronted with the subjectivities of those inside.

\section{Acknowledgements}

We would like to thank the editors of this special issue Migration, Violence, and Vulnerability and the anonymous reviewers for providing critical comments on this article. We also want to thank Vera Silva, Emerson Pessoa, Simone Frangella and Sergio Bontempelli for their encouragement for this project by offering their time and insightful feedback. Last, and most importantly, we are grateful to the women we met inside the centre for sharing their stories and struggles with us, and to the manager and staff members for making the fieldwork possible.

\section{Funding details}

Francesca Esposito's doctoral research was supported by the Portuguese Foundation for Science and Technology [reference: SFRH/BD/87854/2012], and her current work is supported by the British Academy through the Newton International Fellowship Scheme [reference: NIF $\backslash R 1 \backslash 181103$ ]. Raquel Matos's work was supported by the Portuguese Foundation for Science and Technology [reference: UID/CED/04872/2019].

\section{Correspondence:}

Francesca Esposito, Centre for Criminology, University of Oxford, St Cross Building, St Cross Road, Oxford, OX1 3UL, United Kingdom. Email: francesca.esposito@crim.ox.ac.uk

\footnotetext{
1 The study carried out by De Angelis (2020) is the only one based on interviews with former detainees released in the community.

2 It is worth mentioning that in March 2020 immigration detention was, for a few days, at the centre of the public debate as Ihor Homeniuk, a 40-years old Ucranian citizen, was found dead in Lisbon's airport detention facility (see, for instance, Gorjão Henriques, 2020).
} 
3 'Ethnicisation' refers to the process of essentialisation and hierarchisation based, primarily, on cultural characteristics; meanwhile, 'racialisation' is based on physical, behavioural and cultural characteristics.

${ }^{4}$ According to Lykes (2013: 2), 'people's psychosocial praxis' include their voices, creative representations, performances of justice and truth seeking, and actions geared towards realising a better future for themselves and their families (including grassroots organising, and economic and social development projects). Further, 'people's psychosocial praxis is historically contextualized and self-critical. It focuses on the capacities and rights of survivors, protagonists who resist and seek to transform structural oppression' (2).

5 The term used in legislation, and by immigration authorities, is 'removal' (afastamento). However, in keeping with critical migration scholarship and detainees' own accounts, we opted to use the term 'deportation' throughout the paper. When we use the term 'removal', it is always as a quotation in quotation marks.

${ }^{6}$ Act $23 / 2007$ of 4 July 2007, amended by the following laws: 29/2012 of 9 August 2012; 56/2015 of 23 June 2015; 63/2015 of 30 June 2015; 59/2017 of 31 July 2017; 102/2017 of 28 August 2017; 26/2018 of 5 July 2018; 28/2019 of 29 March 2019.

${ }^{7}$ Notably, asylum seekers can be detained on grounds of national security, public order, and public health or whenever there is a risk of absconding. Other reasons for detaining asylum seekers include: lodging an application at a border post; applying for asylum after having been issued with a 'removal order'; and, finally, when one's case fall under the Dublin III Regulation.

8 This trend is actually not new and has been highlighted in the last years (JRS Portugal 2018, 2019).

9 The fieldwork was articulated in two periods (i.e., April 2013 to May 2014 and July 2015 to December 2017) and consisted of segments of 2-5 days spent inside the facility.

${ }^{10}$ The relatively small number of interviews is motivated by the fact that when our fieldwork took place, the detention population was predominantly made up of men. Further, it is worth noting that we did not access the facility on an everyday basis and that some of the women we met did not agree to participate in the study.

${ }^{11}$ Consent forms were prepared in Portuguese, English, French, Spanish, Italian, Chinese, Russian, and Arabic.

12 According to the last Immigration and Borders Service (Serviço de Estrangeiros e Fronteiras 2020) report, Brazilian citizens represent the largest community (25.6\%) of foreign nationals residing in Portugal.

${ }^{13}$ Lusotropicalism is the doctrine elaborated by Brazilian sociologist Gilberto Freyre (1961), which was very influential in the construction of Portuguese colonial ideology, especially at the end of the Third Portuguese Empire (1822-1975). A legacy of this ideology, some scholars argue, persists in the contemporary idea of 'lusophony' (see Castelo 1998).

${ }^{14}$ All real names have been replaced by pseudonyms to protect the anonymity of participants.

15 All the quotes from interviews with Brazilian women were translated in English by the authors.

${ }^{16}$ One of the first reports on this situation appeared in the Magazine Time, in October 2003. See the article 'When the meninas came to the town', http://content.time.com/time/magazine/article/0,9171,517712,00.html

17 We use inverted commas to highlight that these legal categories (i.e., victim of trafficking or refugee) are arbitrary and do not reflect the complexity of the experiences of people crossing international borders.

18 McGregor (2012) highlights the importance of faith as a source of energy, hope and strength that cements the resilience of the people detained. In particular, she shows how the reliance on God, regardless of the faith professed, can provide narrative and performative ways to cope with confinement, enabling people to give meaning to their experiences and maintain a sense of continuity in their lives.

\section{References}

Agier M (2011) Managing the Undesirables. Cambridge: Polity Press.

Alberti G (2010) Across the borders of Lesvos: The gendering of migrants' detention in the Aegean. Feminist Review 94(1): 138-147. https://doi.org/10.1057/fr.2009.44

Baillot H, Cowan S and Munro VE (2014) Reason to disbelieve: Evaluating the rape claims of women seeking asylum in the UK. International Journal of Law in Context 10(1): 105-139. https://doi.org/10.1017/S1744552313000396

Bosworth M (1999) Engendering Resistance: Agency and Power in Women's Prisons. Aldershot: Dartmouth.

Bosworth M (2014) Inside Immigration Detention. Oxford: Oxford University Press.

Bosworth M (2016) Mental health in immigration detention: A literature review. Criminal Justice, Borders and Citizenship: Research Paper No. 2732892. https://papers.ssrn.com/sol3/papers.cfm?abstract id=2732892

Bosworth M (2017) Working in this place turns you racist: Staff, race, and power in detention. In Bosworth M, Parmar A and Vázquez Y (eds) Boundaries of Belonging: Race, Migration and Criminal Justice: 214-228. Oxford: Oxford University Press.

Bosworth M, Fili A and Pickering S (2016) Women's immigration detention in Greece: Gender, control and capacity. In Guia MJ, Koulish R and Mitislegas V (eds) Immigration Detention, Risk and Human Rights: 157-170. New York: Springer.

Bosworth M, Fili A and Pickering S (2018) Women and border policing at the edges of Europe. Journal of Ethnic and Migration Studies 44(13): 2182-2196. https://doi.org/10.1080/1369183X.2017.1408459

Bosworth M and Kellezi B (2014) Citizenship and belonging in a women's immigration detention centre. In Philips C and Webster (eds) New Directions in Race, Ethnicity and Crime: 80-96. Abingdon: Routledge. 
Bosworth M and Slade G (2014) In search of recognition: Gender and staff-detainee relations in a British immigration removal centre. Punishment and Society 16(2): 169-186. https://doi.org/10.1177/1462474513517017

Butler J (2004) Precarious Life: The Powers of Mourning and Violence. New York: Verso.

Campesi G (2015) Hindering the deportation machine: An ethnography of power and resistance in immigration detention. Punishment and Society 17(4): 427-453. https://doi.org/10.1177/1462474515603804

Canning V (2017) Gendered Harm and Structural Violence in the British Asylum System. Abingdon: Routledge.

Castelo C (1998) 'O modo português de estar no mundo': O luso-tropicalismo e a ideologia colonial portuguesa (19331961). Porto: Edições Afrontamento.

Crenshaw K (1991) Mapping the margins: Intersectionality, identity politics, and violence against women of color. Stanford Law Review 43(6): 1241-1299. https://doi:10.2307/1229039

Collins PH (2000) Black Feminist Thought: Knowledge, Consciousness, and the Politics of Empowerment (2nd Edition). New York: Routledge.

Crosby A (2016) Governing immigration through crime at the street level: The metamorphosis of an immigration detention centre in Belgium. Cartografie Sociali. Rivista di Sociologia e Scienze Umani 1(2): 145-166.

Cunha IF (2005) Mundos imaginados: As brasileiras e nos media em Portugal. In Anais do XXVIII Congresso Brasileiro de Ciências da Comunicação. Rio de Janeiro: UERJ.

De Angelis M (2020) Female asylum seekers: A critical attitude on UK immigration removal centres. Social Policy and Society 19(2): 207-224. https://doi.org/10.1017/S1474746419000216

De Genova N (2002) Migrant "illegality" and deportability in everyday life. Annual Review of Anthropology 31: 419447. https://doi.org/10.1146/annurev.anthro.31.040402.085432

De Genova N (2016, November). Detention, deportation, and waiting: Toward a theory of migrant detainability. Global Detention Project: Working Paper No. 18. https://www.globaldetentionproject.org/wpcontent/uploads/2016/12/De-Genova-GDP-Paper-2016.pdf

de Reno Machado IJ (2009) Cárcere público: Processos de exotização entre brasileiros no Porto. Lisboa: Imprensa de Ciências Sociais.

Esposito F, Murtaza A, Peano I and Vacchiano F (2020) Fragmented citizenship: Contemporary infrastructures of mobility containment along two migratory routes. Citizenship Studies 24(5): 625-641 https://doi.org/10.1080/13621025.2020.1784642

Esposito F, Ornelas J, Briozzo E and Arcidiacono C (2019) Ecology of sites of confinement: Everyday life in a detention center for illegalized non-citizens. American Journal of Community Psychology 63(1-2): 190-207. https://doi.org/10.1002/ajcp.12313

Esposito F, Ornelas J, Scirocchi S and Arcidiacono C (2019) Voices from the inside: Lived experiences of women confined in a detention center. Signs 44(2): 403-431. https://doi.org/10.1086/699344

Esposito F, Ornelas J, Scirocchi S, Tomai M, Di Napoli I and Arcidiacono C (2020) "Yes, but somebody has to help them somehow": Looking at the Italian detention field through the eyes of professional nonstate actors. International Migration Review. https://doi.org/10.1177/0197918320921134

Esposito F, Quinto CR, De Masi F, Gargano $O$ and Costa PA (2016) Voices of Nigerian women survivors of trafficking held in Italian centres for identification and expulsion. International Migration 54(4): 133-149. https://doi.org/10.1111/imig.12253

Fassin D (2012) Humanitarian Reason: A Moral History of the Present. Berkeley: University of California Press.

Giuliani G (2018) Race, Nation and Gender in Modern Italy: Intersectional Representations in Visual Culture. London: Palgrave Macmillan.

Gomes MS (2013) 0 imaginário social em Portugal: Uma análise da construção de saberes, das relações de poder e dos modos de subjetivação. Dados 56(4): 867-900. https://doi.org/10.1590/S0011-52582013000400005

Gomes MS (2018) Gênero, colonialidade e migrações: Uma análise de discursos institucionais sobre a 'Brasileira imigrante' em Portugal. Politica and Sociedade 17(38): 404-439. https://doi.org/10.5007/21757984.2018v17n38p404

Gorjão Henriques J (2018a) Estrangeiras detidas no aeroporto de Lisboa estão 'mais expostas' a assédio. Público, 3 September. https://www.publico.pt/2018/09/03/sociedade/noticia/estrangeiras-detidas-no-aeroporto-delisboa-estao-mais-expostas-a-situacoes-de-perigo-1842640

Gorjão Henriques J (2018b) SEF detém crianças requerentes de asilo contra recomendações da ONU. Público, 22 July. https://www.publico.pt/2018/07/22/sociedade/noticia/sef-detem-criancas-requerentes-de-asilo-contrarecomendacoes-da-onu-1838478

Gorjão Henriques J (2019) Detenção de três crianças no aereoporto vai ser investigada. Público, 11 April. https://www.pressreader.com/portugal/edicao-publico-porto/20190411/281505047600212/textview

Gorjão Henriques, J (2020) Direcção do SEF Lisboa demitida depois de PJ deter três inspectores suspeitos de matar ucraniano. Público, 1 April. https://www.publico.pt/2020/04/01/sociedade/noticia/ihor-homenyukucraniano-tera-morrido-maos-inspectores-sef-1910392 
Griffiths M (2013) Living with uncertainty: Indefinite immigration detention. Journal of Legal Anthropology 1(3): 263-286. https://doi.org/10.4059/jla.2013.2616

Hughes SM (2016) Beyond intentionality: Exploring creativity and resistance within a UK immigration removal centre. Citizenship Studies 20(3-4): 427-443. https://doi.org/10.1080/13621025.2016.1142936

Huysmans J (2000) The European Union and the securitization of migration. Journal of Common Market Studies 38(5): 751-777. https://doi.org/10.1111/1468-5965.00263

JRS Portugal (2018) Relatório atividades 2017. Lisboa: JEF. http://www.jrsportugal.pt/relatorio-de-atividades2017/

JRS Portugal (2019) Relatório atividades 2018. Lisboa: JRS. http://www.jrsportugal.pt/relatorio-de-atividades2018/

JRS Portugal (2020) Relatório atividades 2019. Lisboa: JRS. http://www.jrsportugal.pt/relatorio-de-atividades2019/

Kirmayer LJ, Rousseau C and Crépeau F (2004) Research ethics and the plight of refugees in detention. Monash Bioethics Review 23(4): 85-92. https://doi.org/10.1007/bf03351423

Lykes MB (2013) Participatory and action research as a transformative praxis: Responding to humanitarian crises from the margins. American Psychologist 68(8): 774-783. https://doi.org/10.1037/a0034360

Lykes MB, Blanche MT and Hamber B (2003) Narrating survival and change in Guatemala and South Africa: The politics of representation and a liberatory community psychology. American Journal of Community Psychology 31(1-2): 79-90. https://doi.org/10.1023/A:1023074620506

Lykes MB and Hershberg RM (2015) Continuities and discontinuities in human rights violations: Historically situating the psychosocial effects of migration. Journal of Social Issues 71(2): 244-263. https://doi.org/10.1111/josi.12108

Lugones M (2007) Heterosexualism and the colonial/modern gender system. Hypatia 22(1): 186-209.

Lugones M (2010) Toward a Decolonial Feminism. Hypatia 25(4): 742-759.

Matos R (2016) Trajectories and identities of foreign national women: Rethinking prison through the lens of gender and citizenship. Criminology and Criminal Justice 16(3): 350-365. https://doi.org/10.1177/1748895815603776

Matos R and Esposito F (2019) Gender and migration control: Experiences of foreign women detained in Portugal. International Journal of Migration and Border Studies 5(4): 371-391. https://doi.org/10.1504/IJMBS.2019.105809

McGregor J (2012) Rethinking detention and deportability: Removal centres as spaces of religious revival. Political Geography 31: 236-246. https://doi.org/10.1016/j.polgeo.2012.03.003

Mehta R (2014) So many ways to love you/self: Negotiating love in a prison. International Feminist Journal of Politics 16(2): 181-198. https://doi.org/10.1080/14616742.2014.912915

Padilla B (2008) Brasileiras en Portugal: De la transformación de las diversas identidades a la exotización. Amérique Latine Histoire and Mémorie. Les Cahiers ALHIM 14.

Padilla B, Gomes M and Fernandes G (2010) Ser brasileira em Portugal: Imigração, género e colonialidade. In Carvalho F, Badet Souza M, Callou M and Rubiralta M (eds) 1ํo Seminário de Estudos sobre Imigração Brasileira na Europa, Barcelona, Spain, 25-27 November 2010: 113-112. Barcelona: Coletivo Brasil Catalunya.

Pais J M (2011) Mothers, whores and spells: Tradition and change in Portuguese sexuality. Ethnography 12(4): 445-465. https://doi.org/10.1177/1466138110393790

Peano I (2012) Excesses and double standards: Migrant prostitutes, sovereignty and exceptions in contemporary Italy. Modern Italy 17(4): 419-432. https://doi.org/10.1080/13532944.2012.706994

Piscitelli A (2008a) Interseccionalidades, categorias de articulação e experiências de migrantes brasileiras. Sociedade e Cultura 11(2): 263-274. https://doi.org/10.5216/sec.v11i2.5247

Piscitelli A (2008b) Looking for new worlds: Brazilian women as international migrants. Signs 33(4): $784-793$. https://doi.org/10.1086/528747

Pontes L (2004) Mulheres brasileiras na mídia portuguesa. Cadernos Pagu 23: 229-256. https://doi.org/10.1590/S0104-83332004000200008

Provedor de Justiça (2017) Tratamento dos cidadãos estrangeiros em situação irregular ou requerentes de asilo nos centros de instalação temporária ou espaços equiparados. Lisboa: Mecanismo Nacional de Prevenção.

https://www.provedorjus.pt/site/public/archive/doc/Cidadaos estrangeiros e o direito a um tratamento digno.pdf

Riessman CK (2008) Narrative Methods for the Human Sciences. Thousand Oaks: SAGE.

Rigo E (2019) Re-gendering the border: Chronicles of women's resistance and unexpected alliances from the Mediterranean border. ACME 18(1): 173-186.

Robjant K, Hassan R and Katona C (2009) Mental health implications of detaining asylum seekers: Systematic review. British Journal of Psychiatry 194(4): 306-312. https://doi.org/10.1192/bjp.bp.108.053223 
Sacramento 0 and Ribeiro M (2011) Vidas embargadas: a institucionalização temporária de estrangeiros 'ilegais' em Portugal no contexto das actuais políticas de imigração. In Silva P, Sacramento O and Portela J (eds) Etnografia e intervenção social: por uma 'praxis' reflexiva: 141-172. Lisboa: Colibri.

Santos G, Soares C, Rebelo R and Ferreira P (2018) Mental health and undocumented migrants in Portugal. Journal of Public Mental Health 17(4): 200-209. https://doi.org/10.1108/JPMH-11-2017-0039

Serviço de Estrangeiros e Fronteiras (2020) Relatório de imigração, fronteiras e asilo 2019. Barcarena, Oeiras. https://sefstat.sef.pt/Docs/Rifa2019.pdf

Spivak GC (1988) Can the Subaltern Speak? In Nelson C and Grossberg L (eds) Marxism and the Interpretation of Culture: 271-313. Basingstoke: Macmillan Education.

Steel Z and Silove D (2004) Science and the common good: Indefinite, non-reviewable mandatory detention of asylum seekers and the research imperative. Monash Bioethics Review 23(4): 93-103. https://doi.org/10.1007/bf03351424

Stolke V (2006) 0 enigma das interseções: classe, 'raça', sexo, sexualidade: A formação dos impérios transatlânticos do século XVI ao XIX. Revista Estudos Feministas 14(1): 15-42. https://doi.org/10.1590/S0104$\underline{026 X 2006000100003}$

Taliani S (2012) Coercion, fetishes and suffering in the daily lives of young Nigerian women in Italy. Africa 82(4): 579-608. https://doi.org/10.1017/S0001972012000514

Turnbull S (2016) 'Stuck in the middle': Waiting and uncertainty in immigration detention. Time and Society 25(1): 61-79. https://doi.org/10.1177/0961463X15604518

von Werthern M, Robjant K, Chui Z, Schon R, Ottisova L, Mason C and Katona C (2018) The impact of immigration detention on mental health: A systematic review. BMC Psychiatry 18(1): 382. https://doi.org/10.1186/s12888$\underline{018-1945-y}$

\section{Legislation cited}

Act No. 23/2007 (Portugal)

Act No. 27/2008 (Portugal)

Act No. 26/2014 (Portugal)

Act No. 34/1994 (Portugal)

Decree-Law No. 44/2006 (Portugal) 